\title{
Fokus areas vir 'n bestuursinligtingstelsel vir top-, middel- en laervlakbestuur in 'n finansiële instelling
}

\author{
P.J.S. Bruwer \& D. van der Walt \\ Nagraadse Bestuurskool, P.U. vir C.H.O., Potchefstroom 2520, Republiek van Suid-Afrika \\ Ontvang 5 Februarie 1991; aanvaar 9 April 1992
}

\begin{abstract}
Focus areas for a management information system for top, middle and lower level management in a financial institution. This research project was conducted at one of South Africa's major banks. This bank has a client base of approximately five million clients and approximately eight million active accounts. Since the term 'Management Information Systems' was relatively new to this bank, the purpose of this project was to do a critical evaluation of the existing management information system. This was done by means of a questionnaire to top, middle and lower level management in the bank. These data were processed by making use of stepwise linear regression as well as all possible subset multiple linear regression methods. A number of critical success factors were identified and prioritized for each of four subsets of the population. These subsets are the following: top and middle management; regions; operational management; and all users of the information system. A number of recommendations were made for establishing an improved service provided by the systems development team.
\end{abstract}

\begin{abstract}
Hierdie studie is by een van die grootste bankinstelling in Suid-Afrika gedoen, 'n lid van 'n groep wat baie pertinent en sterk in die Suid-Afrikaanse ekonomie staan. Dié bank het tans nagenoeg vyf miljoen kliënte en nagenoeg agt miljoen rekeninge wat in bedryf is. Aangesien die term 'Bestuursinligtingstelsel' relatief nuut was by die bank, was die doel van die projek om ' $n$ kritiese evaluasie uit te voer rakende die bestaande bestuursinligtingstelsel. In hierdie navorsingsprojek is daar op 'n wetenskaplike wyse, met behulp van 'n vraelys, probleemareas geïdentifiseer ten opsigte van die huidige bestuursinligtingstelsel. Vier onderafdelings van die studiepopulasie is geïdentifiseer, naamlik top- en middelvlakbestuur; streke; operasionale bestuur; en alle gebruikers van die inligtingstelsel. Aanbevelings word gemaak om 'n effektiewe inligtingstelsel vir top-, middel- en operasionele bestuur daar te stel.
\end{abstract}

\section{Inleiding}

Die hoofdoel van dié navorsingsproiek was om te bepaal of die bestaande bestuursinligtingsbehoeftes bevredig kan word deur 'n rekenaargebaseerde bestuursinligtingstelsel te skep, deur middel van die onttrekking en verwerking van data op die huidige databasisse en stelsellêers op die hoofraam, soos tans in gebruik by die bankinstelling.

Die navorsing was beperk tot die spesifieke bankinstelling se bestuurspan. Aandag is geskenk aan die bestuursinlig. tingsbehoeftes van die totale bestuurspan. Hier word meer spesifiek verwys na topbestuur wat meer in strategiese inligting belangstel, middelbestuur wat inligting benodig vir taktiese beplanning en operasionele bestuur vir bedryfsinligting en eindgebruikerverwerking.

\section{Bestuursinligting en sy gebruikers in die bank}

Die bank het teen die einde van Maart 1990 in totaal meer as 5000 personeellede gehad. Uit die totale personeelkorps maak ongeveer 200 personeellede op 'n gereelde grondslag van bestuursinligting gebruik.

Byna alle bestuursinligting word in die vorm van verslae aan die gebruikers beskikbaar gestel. Vyf van die bestuurders uit die topbestuursgroep het by die aanvang van hierdie projek 'n persoonlike rekenaar op hul lessenare gehad wat 'n bestuursinligtingspakket, Executive Edge, in bedryf het. Hierdie pakket gebruik data wat maandeliks vanaf die hoofraam onttrek word om verskillende grafieke op te stel wat dan as bestuursinligting gebruik word. Baie tyd word tans aan die ontwikkeling van hierdie stelsel bestee sodat topbestuur in die nabye toekoms feitlik glad nie meer bestursinligting in papiervorm nie, maar wel op 'n persoonlike rekenaar, sal ontvang. Ongeveer 600 grafieke was teen einde Junie 1990 reeds beskikbaar op die persoonlike rekenaars en die ontwikkeling hiervan word op ongeveer 100 per maand bereken. Die totale bestuursinligtingstelsel op hierdie persoonlike rekenaars sal teen die einde van die huidige ontwikkelingsfase ongeveer 1200 grafieke behels.

Ander gebruikers van die bestuursinligting kry hul inligting slegs in verslagvorm. Indien hulle slegs in 'n klein deel van die inligting belangstel, het hulle geen ander keuse as om deur die hele verslag te lees nie. Hierdie verslae word vanuit die hoofkantoor na die gebruikers versprei. Verslae is deur die jare ontwikkel namate die behoefte daarvoor ontstaan het.

As gevolg van die feit dat daar soveel ad hoc-versoeke vanuit die verskillende streke is, is 'n geruime tyd gelede 'n pakket genaamd Ergo aangekoop. Ergo is 'n pakket wat op eindgebruikerverwerking gerig is. Hierdie pakket 'n verslaggenereerder, stel die gebruiker daarvan in staat om sy eie verslae op te stel volgens sy unieke behoeftes. Data wat deur die pakket gebruik word vir verslaggewing moet vooraf op 'n spesiaal-opgestelde databasis geplaas word vir onttrekking deur die pakket. Die doel met die aankoop van die pakket was dat elke streek oor 'n aantal personeellede wat opgelei is en die nodige gebruikskennis van die pakket opgedoen het, sou beskik. Indien 'n ad hoc-versoek ontstaan, word die versoek aan 'n gebruikskenner van hierdie pakket gerig. Hierdie persoon is dan verantwoordelik om met behulp van Ergo 'n verslag op te stel indien die nodige data op die databasis beskikbaar is. Dit was 'n groot stap in die rigting van eindgebruikerverwerking.

Ongelukking kan die hele gebruikerkorps dit nie ten volle benut nie, omdat Ergo 'n baie groot effek op reaksietye het vanweë die feit dat dit baie verwerkingstyd benodig. Die gebruik van Ergo moet dus beperk word. Aangesien Ergo nie baie ekonomies is nie, word tans oorweging geskenk aan potensiële plaasvervangers. 
Op die oomblik verleen Ergo slegs toegang tot 'n gefiltreerde kopie van die hooftransaksieverwerkingsdatabasis. Verdere uitbreiding vind tans ook ten opsigte van die gebruik van dié pakket op die grootboekstelsel-databasis van die bank plaas.

\section{HIerargie betrokke by bestuursinligting}

Bestuursinligting het sy oorsprong by 'n aantal omgewings in die bank. Hierdie omgewings word elk kortliks bespreek.

\section{Bestuursinligtingontleding}

Binne die hièrargie van hierdie bank is ' $n$ afdeling wat verantwoordelik is vir bestuursinligtingontleding. Die personeel van hierdie afdeling se taak is om met behulp van hul kennis na bestuursinligting te kyk en so spoedig moontlik neigings te identifiseer. Hulle moet dan hierdie neigings monitor en deurvoer na topbestuur. Topbestuur, op sy beurh, sal dan optree ooreenkomstig die inligting tot sy beskikking.

Weens die gebrek aan geskikte bestuursinligting voordat die bestuursinligtingsafdeling binne die stelselontwikkelingsafdeling gestig is, het laasgenoemde afdeling self inligting begin versamel. Hulle het reeds oor 'n aantal jare begin om historiese data uit ' $n$ verskeidenheid bronne te versamel. 'n Baie groot probleem is egter dat hulle tans soveel tyd aan die insameling van bestuursinligting bestee, dat hulle nie meer tyd het om hul oorspronklike funksies te verrig nie.

Hierdie afdeling beskik tans oor 'n magdom bestuursinligting wat op papier of 'n persoonlike rekenaar vasgelê is. Daar is selfs ' $n$ aantal maandelikse lopies met behulp van die Ergo-pakket op die hoofraam geplaas om bestuursinligting te ontrek. Byna al die bestuursinligting wat hierdie afdeling versamel, ontrek hulle self weer op een of ander wyse uit 'n verskeidenheid van bronne.

\section{Bestuursinligtingsafdeling}

'n Tweede afdeling waaraan aandag geskenk word, is die bestuursinligtingsafdeling binne die stelselontwikkelingsdepartement. Weens die toenemende vraag na bestuursinligting binne die bank, was daar 'n baie groot behoefte aan so 'n afdeling wat toe in Mei 1989 gestig is. Die aanvanklike personeel van die afdeling het slegs uit drie lede bestaan. Die funksies van hierdie afdeling kan in twee hoofkategorieè verdeel word, naamlik:

- die daarstelling van 'n topbestuursinligtingstelsel;en

- die daarstelling van ' $n$ inligtingstelsel wat sal voorsien in die inligtingsbehoeftes van die middelbestuur, takbestuur en ander besture.

Die personeel van die afdeling het intussen uitgebrei na ses personeellede. Die bestuursinligtingafdeling val binne die afdeling Navorsing en Ontwikkeling.

\section{Inligtingsentrum}

Binne die hiêrargie van die stelselondersteuningsdepartement funksioneer die inligtingsentrum. Die taak van hierdie afdeling is om om te sien na die eindgebruikerverwerkingsbehoeftes binne die bank. Dit is dan juis ook hierdie afdeling se taak om 'n Ergo werksomgewing daar te stel en te bedryf. Die personeel van hierdie afdeling verskaf ook verder 'n omgewing waarin die finansiële departement modellering kan doen. Hierdie modellering word gebaseer op die bestuursinligtingdatabasis wat bedryf word deur die bestuursinligtingafdeling in die stelselontwikkelingsdepartement. Dié modellering se hooftaak is om te kyk na die kostes van kapitaal en gevolglik word daar baie van 'wat as?' ('what if?') analises gebruik gemaak.

\section{Probleemareas}

Daar bestaan ' $n$ aantal entiteite binne die bank wat in terme van bestuursinligting potensiële probleemareas is. Vervolgens sal daar kortliks na elk van hierdie areas gekyk word.

\section{Bestuursinligtingdefinisie}

Weens die feit dat die begrip 'bestuursinligting' nog relatief nuut is binne die bank, bestaan daar nog geen behoorlike definisie daarvoor in die bankwese nie. Vroeerr, voordat die bestuursinligtingsafdeling gestig is, is die meeste bestuursinligting uit die verskillende transaksieverwerkingstelsels gegenereer. Dit is nog tot 'n groot mate steeds die geval. Daar bestaan vier hooftransaksieverwerkingafdelings, en elkeen van hierdie afdelings word verder onderverdeel in verskillende onderafdelings.

\section{Bestuursinligting in die bank}

Bestuursinligting binne die bank word in 'n aantal verskillende omgewings geproduseer. Een van die omgewings is onder andere die bedryfsdepartement. As gevolg van hierdie verskillende omgewings binne die bank skep dit groot verwarring by die gebruikers daarvan. 'n Mens kan die gebruikers gevolglik nie kwalik neem as hulle ' $n$ verkeerde persoon kontak wanneer hulle probleme ondervind nie. Daar bestaan wel ' $n$ aantal tegniese analiste binne die stelselontwikkelingsdepartement wat die taak het om om te sien na die koördineering tussen gebruikers en die departement.

Hierdie tegniese analiste is almal spesialiste op hulle gebied en baie hulpvaardig. Die gebruikers verstaan egter nie altyd as ' $n$ analis hom of haar nie kan help nie, maar na iemand anders verwys. Uit gesprekke met gebruikers was dit duidelik dat hulle nie die stelselontwikkelingsomgewing verstaan nie. Hulle besef nie altyd dat elkeen op sy eie bepaalde terrein spesialiseer en gevolglik nie 'n spesialiskenner van die totale omgewing is nie. 'n Tegniese analis is nie tans aan die bestuursinligtingafdeling toegewys nie. Dit het tot gevolg dat die ontwikkelingspan baie van hul tyd moet bestee om die gebruikers se navrae te behartig. Waardevolle tyd gaan hierdeur vir die ontwikkelingspan verlore.

\section{Rekenaargeletterdheid}

Uit gesprekke met gebruikers blyk dit dat van hulle nie rekenaargeletterd is nie. Hierby word sommige lede van die topbestuurspan ingesluit. Dit is 'n probleem wat kan meebring dat die gebruikers nie altyd verstaan wat met sommige terme bedoel word nie. Hul verstaan ook nie altyd waarom 'n taak of ' $n$ oplossing van 'n probleem 'n bepaalde tyd neem om voltooi te word nie. Dit bring dan ook mee dat hulle dit nie wil aanvaar as gesê word dat daar nie aan 'n bepaalde versoek voldoen kan word binne die stelsel soos dit tans funksioneer nie, maar dat aansienlike aanpassings 
gemaak moet word. 'n Verdere punt wat moeilik begrypbaar is vir sommige gebruikers, is dat die bestuursinligtingdatabasis en die transaksieverwerkingdatabasis verskillende databasisse is en selfs op twee individuele hoofraamrekenaars funksioneer.

Die bewering dat sommige lede van die topbestuurspan nie rekenaargeletterd is nie, veroorsaak dat sekere lede van die stelselontwikkelingspan van mening is dat sommige besluite lank neem om gefinaliseer te word. Die gevoel blyk verder te wees dat niemand die finale besluit wil neem nie en soms verantwoordelikhede probeer ontduik.

\section{Streeksgebondenheid}

As gevolg van die bank se grootte word die bank in verskillende streke verdeel. Hierdie streke funksioneer elkeen met sy eie topbestuurspan. Elke streek word op 'n individuele wyse bestuur met as riglyn die sleutelsuksesfaktore van die bank. Omdat die topbestuur van die bank glo in vrye keuses oor hoe elke streek bedryf behoort te word, het elke streek oor die jare sy eie unieke manier ontwikkel om sy take te bedryf.

Juis as gcvolg van hierdie 'vryheid' van die streke is daar 'n redelike groot verskil rakende die bestuursinligtingbehoeftes wat hulle het. Koördineering tussen die streke om die bestuursinligtingbehoeftes te bepaal, is dus geen maklike taak nie. Elke streek voel dat sy manier van dinge doen die beste is, en wil nie sommer instem tot 'n kompromie in 'n poging om almal tevrede te stel nie.

\section{Navorsingsmetodiek}

Met die bogenoemde gegewens as die scenario waarbinne die navorsing gedoen is, is daar voortgegaan deur ' $n$ vraelys op te stel ten einde die tekortkominge binne die bestaande bestuursinligtingstelsel te probeer uitwys.

\section{Ontwikkeling van die vraelys}

By die opstel van 'n vraelys vir 'n studie soos dié is dit belangrik om te verseker dat al die vrae wat gevra word, verband hou met die doelwit van die studie.

'n Doelwit van die studie was onder andere om aanbevelings te maak ter verbetering van die diens wat déur die stelselontwikkelingsdepartement gelewer word, deur gebruik te maak van bestaande rekenaarfasiliteite. Ten einde die toegedeelde hulpbronne doeltreffend en effekticf aan te wend, en om te bepaal in watter mate die huidige bestuursinligtingstelsel in hierdie behoefte voorsien, moes die vraelys daarvolgens ontwerp word. 'n Doelwit van die vraelys moes dus wees om die gebruikers se tevredenheid met die bestaande bestuursinligtingstelsel te meet.

Bailey et al. (1983: 530) het in sy studie 'n 'standaard' vraelys opgestel ter evaluering van 'n bestaande bestuursinligtingstelsel. Hierdie vraelys bestaan uit 'n groep van 39 verskillende attribute. Die doel met die ontwerp van hierdie instrument is om dit te gebruik om die gemiddelde vlakke van tevredenheid te bepaal in die verskillende situasies van die gebruikers van die bestuursinligtingstelsel.

Bruwer (1987: 46) het op sy beurt 'n vraelys opgestel vir evaluering van bestuursinligtingstelsels wat reeds baie suksesvol gebruik is in 'n aantal groot sowel as klcin organisasies. Die doel van hierdie vraelys is om evaluering te doen van die belangrikheid en werkverrigting van inligtingstelselsaturibute. Hy gebruik hierdie vraelys getitel 'Diagnose metodologie inligtingstelsels (DMIS)' in ondersoeke wat hy ondemeem aangaande suksesvolle implementering van bestuursinligtingstelsels.

Verbandhoudende vrae is uit beide die vraelyste geneem om die vraelys vir hierdie studie saam te stel. Nadat 'n voorlopige vraelys saamgestel is, moes sommige aanpassings gemaak word om dit geskik te maak vir dié projek. Hierdie aanpassings en die vraelys in sy geheel is met 'n aantal persone bespreek om seker te maak dat al die betrokke partye die vrae sal verstaan en dat 'n suksesvolle studie hiermee uitgevoer kon word. Partye waarmee beraadslaag is vir die opstel en redigering van die vraelys sluit die volgende in:

- Streeksrekenmeesters

- Produkbestuurders

- Interne ouditeurs

- Middelbestuurders by hoofkantoor

- Takbestuurders

- Stelselontwikkelingsbestuurders

'n Bestuursinligtingstelsel is baie duidelik in die vraelys gedefinieer, sodat alle respondente dieselfde daaronder sou verstaan. Die vraelys soos uitgestuur aan die verskillende gebruikers bestaan uit drie afdelings (Van der Wath, 1990: 101-116). Afdeling A het ten doel om demografiese inligting van die respondent in te win. In Afdeling $B$ is die doel om te bepaal wat die respondent se gevoel van belangrikheid is oor elk van die 36 aspekte ten einde 'n suksesvolle bestuursinligtingstelsel daar te stel. Die vrae in Afdeling $\mathrm{C}$ is presies dieselfde as dié in Afdeling B. Die enigste verskil is dat daar in Afdeling $C$ van die respondent verwag is om die 36 aspekte te evalueer soos dit tans in die organisasie ondervind word. 'n Laaste vraag in die afdeling is later gebruik as die afhanklike veranderlike vir hierdie studie. Die vraag lui soos volg: "In totaliteit gesien, tot watter mate bevredig die huidige bestuursinligtingstelsel $\mathbf{u}$ inligtingsbehoeftes?'

Die doelwit van beide Afdelings $B$ en $C$ is om te bepaal wat die verskil is wat die respondent ondervind tussen wat as belangrik geag word en wat werklik ondervind word. Die antwoord wat hier verkry is, sal later gebruik word om 'n prioriteitsvolgorde toe te ken aan die verskillende veranderlikes wat die grootste effek het op die afhanklike veranderlike. Afdelings $B$ en $C$ word op 'n 7-puntskaal beantwoord, teenoor Afdeling $A$ wat slegs bepaal in watter streek en waar in die bank se hiërargie die respondent val.

Die 36 vrae wat in afdelings $A$ en $B$ van die vraelys vervat is, word vervolgens gelys (Van der Wath, 1990: 104-115):

1. U deelname aan stelselontwikkeling

2. Betroubaarheid van inligting

3. Kennis van ontwikkelings- en bedryfskostes van die bestuursinligtingstelsel(BIS)

4. Akkuraatheid van die uitvoerinligting

5. Ondersteuning van u direkte bestuur, in die gebruik van die BIS

6. Kommunikasic tussen stelselontwikkeling (SO)-personeel en gebruikersbestuurders

7. Suksesvolle stelseltoetsing

8. Buigbaarheid in gebruik van die BIS 
9. Gemak van gebruik van die BIS

10. Relevantheid van inligting in bereiking van bedryfsdoelwitte

11. Tydigheid van die inligting

12. Volledigheid van die uitvoerinligting

13. Doeltreffende gebruikersdokumentasie

14. Werksverhouding tussen die gebruikers en die SO-personeel

15. Voldoende prosedures om foute te rapporteer

16. Vertroudheid met die gedeelte van die BIS wat u affekteer

17. Vinnige omkeentyd vir veranderinge aan die bestaande stelsel

18. Beskikbaarheid van inligting

19. Bevrediging van u behoeftes in terme van die formaat waarin $u$ inligting ontvang

20. Bevredigende regstelling van foute

21. Opleiding wat verskaf is vir die gebruik van die BIS

22. Volume (toepaslike hoeveelheid) van uitvoerinligting uit die BIS

23. Ondersteuning van SO-personeel aan gebruiker in terme van oplossing van probleme

24. Voorsiening van 'n ouditspoor

25. Kort tydsverloop by ontwikkeling van nuwe modules in die BIS

26. Gebruikersvertroue in die BIS

27. Ondersteunende houding van SO-personeel teenoor gebruikers

28. Of gebruikers die BIS se datavloei verstaan

29. Kennis van tegniese aspekte van die BIS vir die gebruiker

30. Aanpasbaarheid van die stelsel vir verandering in behoeftes

31. Topbestuursbetrokkenheid in die definiëring en monitor van die BIS-beleid

32. Algehele koste-effektiwiteit van die BIS

33. Tydsverloop vir oplossing van probleme deur die SOdepartement

34. Mate waartoe die BIS voldoen aan gebruiker verwagtinge

35. Sukses wat die SO-departement behaal met BIS veranderinge

36. Geoutomatiseerde gebruikermanipulasie van die BIS (byvoorbeeld 'wat as?')

\section{Studiepopulasie}

Hierdie vraelys is an die totale groep bestuursinligtingstelselgebruikers binne die bank gestuur (270 gebruikers). Die groep het die volgende ingesluit:

- Topbestuur

- Streekbestuurders

- Rekenmeesters

- Produksiebestuurders

- Takbestuurders

- Ander besluitnemers

Respons uit die studie

'n Respons van $43.3 \%$ is terugontvang $(\mathrm{N}=117)$. Die respons wat verkry is, was voldoende om wetenskaplike verwerking van die data in die vraelyste te doen.
Geen direkte navrae is gerig ten opsigte van die inhoud van die vraelys nie. Dit toon aan dat die vraelys van so 'n aard was dat dit vir almal relatief maklik was om te voltooi.

Vier vraelyste is terugontvang wat so swak voltooi was dat hulle nie gebruik kon word nie. Dié vier vraelyste is nie ingereken in die totale respons van $43.3 \%$ nie.

\section{Ontleding van die vraelys}

Die verskillende attribute wat ontleed is, beoordeel elk watter bydrae dit lewer tot die uiteindelike sukses of mislukking van die bestuursinligtingstelsel. In hierdie studie word die kriteria vir sukses van so 'n stelsel gemeet aan die waarneming van die gebruikers oor die bevrediging wat die stel. sel verskaf ten opsigte van hul bestuursinligtingstelselbehoeftes.

Weens die volume faktore betrokke by die meting, is daar van die hoofraampakket BMDP (Dixon \& Brown, 1983) gebruik gemaak. Die hoofrede hiervoor was om gebruik te maak van die beskrywende, meer veranderlike statistiese metodiek. Faktoranalise is gebruik om verwantskappe tussen die veranderlikes te probeer beskryf deur na korrelasiepatrone in die data te soek.

Eerstens was die doelwit hiervan om die aantal faktore te reduseer tot die wat die grootste bydrae lewer tot die totale variansie wat deur hierdie veranderlikes verklaar word. $\mathrm{Om}$ 'n verbetering aan die huidige stelsel te bewerkstellig, sal dit nodig wees om in die toekoms aan hierdie faktore indringend aandag te skenk.

'n Verdere doelwit was om die data meer sinvol te interpreteer deur die ondersoek van verwante veranderlikes om onderliggende struktuur en versteekte dimensies tussen veranderlikes op te spoor.

Meervoudige regressie toon egter ook verwantskappe tussen 'n afhanklike en verskeie onafhanklike veranderlikes wat ondersoek word. Diskriminantanalise is toe aangewend om die effek van korrelasie tussen die onafhanklike veranderlikes te verminder. Hierdeur is bepaal watter veranderlikes die variansie van intergroepverskille in gemiddeldes die beste verklaar. Indien slegs 'n paar veranderlikes die meeste variansie verklaar, verteenwoordig hierdie veranderlikes die belangrikste faktore in die sukses van die bestuursinligtingstelsel.

\section{Toepassing van regressiemetodes}

Die laaste vraag op die lys is gebruik as die afhanklike veranderlike. Vrae 1-36 van die vraelys is gebruik as onafhanklike veranderlikes.

Die program BMDP2R (Dixon, 1983: 251) is gebruik vir die stapsgewyse regressie-ontleding. Hierdie program gee aan

tistiese inligting rakende die veranderlikes wat gebruik is. In Tabel 1 word 'n opsomming van die gemiddeldes en die standaardafwyking van elke attribuut in die model gegee. Verder gelys in die tabel is die verskil tussen die gemiddeldes soos wat die gebruikers meen hoe belangrik die verskillende attribute is en soos hul dit werklik ondervind.

\section{Ontleding van die vraelys}

Vier stelle lopies van die program is gedoen om ontledings 
uit verskillende gebruikersgroepe van die bestuursinligtingstelsel te kon doen. Die lopies was soos volg:

1. Streke - Slegs gebruikers wat in een van die agt streke (waarin die bank onderverdeel is) funksioneer, is hierby ingesluit; dit wil sê hoofkantoorpersoneel is uitgesluit.

2. Top- en middelbestuur - Topbestuur en middelbestuur van die hoofkantoorfunksies, sowel as die topbestuur van elke streek is hier ingesluit. (Afdeling A-poste: topbestuur, streekbestuurder, rekenmeester, hoofkantoor.)

3. Laevlakbestuur - Hier word verwys na toesighoudende personeel en ander. (Afdeling A-poste: takbestuurder, verkopebestuurder en ander.)

4. Totaal - Al die gebruikers is hier ingesluit.

Nadat die eerste stapsgewyse regressie voltooi is, is voortgegaan en program BMDP9R (Dixon, 1983: 264) gebruik met data verkry uit die vorige stap (BMDP2R). Die doel hiervan was om alle moontlike deelversamelings van veran-

Tabel 1 Attribuut gemiddeldes

\begin{tabular}{|c|c|c|c|c|c|}
\hline \multirow{2}{*}{$\begin{array}{l}\text { Aturi- } \\
\text { buut }\end{array}$} & \multicolumn{2}{|c|}{ Belangrikheid } & \multicolumn{2}{|c|}{ Werklik } & \multirow{2}{*}{$\begin{array}{l}\text { Verskil } \\
\text { Bel.-werk. }\end{array}$} \\
\hline & Gern. & Std. Afw. & Gem. & Std.Afw. & \\
\hline 1 & 4.876 & 1.675 & 3.168 & 1.481 & 1.708 \\
\hline 2 & 6.283 & 1.161 & 4.133 & 1.398 & 2.151 \\
\hline 3 & 4.097 & 1.581 & 2.683 & 1.501 & 1.414 \\
\hline 4 & 6.389 & 1.089 & 4.097 & 1.363 & 2.292 \\
\hline 5 & 5.549 & 1.336 & 4.336 & 1.462 & 1.212 \\
\hline 6 & 5.558 & 1.260 & 3.540 & 1.350 & 2.018 \\
\hline 7 & 6.071 & 1.400 & 3.469 & 1.337 & 2.602 \\
\hline 8 & 5.664 & 1.049 & 3.664 & 1.215 & 2.000 \\
\hline 9 & 5.885 & 1.148 & 3.991 & 1.236 & 1.894 \\
\hline 10 & 6.150 & 1.144 & 4.416 & 1.307 & 1.735 \\
\hline 11 & 6.204 & 1.219 & 3.894 & 1.305 & 2.310 \\
\hline 12 & 6.133 & 1.106 & 4.115 & 1.238 & 2.018 \\
\hline 13 & 5.699 & 1.217 & 3.805 & 1.315 & 1.894 \\
\hline 14 & 5.496 & 1.276 & 3.788 & 1.392 & 1.708 \\
\hline 15 & 5.708 & 1.280 & 3.566 & 1.274 & 2.142 \\
\hline 16 & 5.867 & 1.379 & 3.885 & 1.444 & 1.982 \\
\hline 17 & 5.982 & 1.030 & 3.416 & 1.400 & 2.566 \\
\hline 18 & 6.292 & 1.041 & 3.929 & 1.368 & 2.363 \\
\hline 19 & 6.027 & 1.022 & 3.903 & 1.142 & 2.124 \\
\hline 20 & 5.991 & 1.192 & 3.858 & 1.238 & 2.133 \\
\hline 21 & 5.628 & 1.338 & 3.195 & 1.349 & 2.434 \\
\hline 22 & 5.133 & 1.333 & 3.991 & 1.082 & 1.142 \\
\hline 23 & 5.708 & 1.237 & 3.929 & 1.374 & 1.779 \\
\hline 24 & 5.106 & 1.284 & 3.752 & 1.306 & 1.354 \\
\hline 25 & 5.310 & 1.233 & 3.327 & 1.081 & 1.982 \\
\hline 26 & 6.159 & 1.131 & 3.726 & 1.227 & 2.434 \\
\hline 27 & 5.717 & 1.206 & 4.186 & 1.162 & 1.531 \\
\hline 28 & 5.301 & 1.315 & 3.416 & 1.266 & 1.885 \\
\hline 29 & 3.681 & 1.508 & 2.558 & 1.267 & 1.124 \\
\hline 30 & 5.938 & 1.128 & 3.496 & 1.218 & 2.443 \\
\hline 31 & 5.080 & 1.331 & 3.504 & 1.218 & 1.575 \\
\hline 32 & 5.071 & 1.462 & 3.540 & 1.118 & 1.531 \\
\hline 33 & 5.788 & 1.168 & 3.487 & 1.111 & 2.301 \\
\hline 34 & 5.876 & 1.207 & 3.858 & 1.043 & 2.018 \\
\hline 35 & 5.496 & 1.269 & 3.894 & 1.168 & 1.602 \\
\hline 36 & 5.381 & 1.291 & 3.257 & 1.159 & 2.124 \\
\hline
\end{tabular}

derlikes te ondersoek om sodoende die kombinasie van veranderlikes

riansie te verklaar.

'n Prioriteitsfaktor is gekoppel aan die veranderlikes om 'n volgorde van belangrikheid van die sukses van die stelsel uit te wys. Die wyse waarop dit gedoen is, is deurdat die verskil tussen die gemiddeldes verkry uit Afdeling B (belangrikheid) en Afdeling $C$ (werklik) vermeningvuldig is met die bydrae van die veranderlike tot $R^{2}$.

Vervolgens word die uitslag van die vier stelle statistiese ontledings wat gedoen is afsonderlik gelys. Hierdie faktore word vervolgens in volgorde van belangrikheid gelys vir elk van die vier stelle statistiese ontledings.

\section{Streke}

Die agt faktore wat $64.6 \%$ van die variansie van die afhanklike veranderlike verklaar het en as krities belangrik beskou word om die diens aan die streke te verbeter, is:

10. Relevantheid van inligting

26. Gebruikersvertroue in die bestuursinligtingstelsel

34. Mate waartoe die bestuursinligtingstelsel voldoen aan die gebruikers se verwagtinge

7. Suksesvolle stelseltoetsing

3. Kennis van ontwikkelings- en bedryfskostes van die bestuursinligtingstelsel

25. Kort tydsverloop by ontwikkeling van nuwe modules in die bestuursinligtingstelsel

32. Algehele koste-effektiwiteit

22. Volume (toepaslike hoeveelheid) van die uitvoerinligting uit die bestuursinligtingstelsel

Top- en middelbestuur

Die 18 faktore wat $97.6 \%$ van die variansie van die afhanklike veranderlike verklaar het en dus die grootste effek sal hê in die bereiking van 'n suksesvolle bestuursinligtingstelselvir hierdie groep gebruikers is:

7. Suksesvolle stelseltoetsing

36. Geoutomatiseerde gebruikersmanipulasie van die BIS

15. Voldoende prosedures om foute te rapporteer

8. Buigbaarheid wat verskaf is vir die gebruik van die BIS

21. Opleiding wat verskaf is vir die gebruik van die BIS

10. Relevantheid van inligting tot bereiking van bedryfsdoelwitte

2. Betroubaarheid van inligting

35. Sukses wat die SO-departement behaal met die BIS veranderinge

28. Of gebruikers die BIS se datavloei verstaan

3. Kennis van ontwikkelings- en bedryfskostes van die BIS

16. Vertroudheid met die gedeelte van die BIS wat u affekteer

17. Vinnige omkeertyd vir veranderings in die bestaande stelsel

26. Gebruikersvertroue in die BIS

18. Beskikbaarheid van inligting

34. Mate waartoe die BIS voldoen aan gebruikersverwagtinge

33. Tydsverloop vir oplossing van probleme deur die SO-departement

29. Kennis van tegniese aspekte van die BIS vir die gebruiker 
22. Volume (toepaslike hoeveelheid) van die uitvoerinligting uit die BIS

\section{Laenlakbestuur}

Die nege faktore vir hierdie groep gebruikers $(62.8 \%$ verklaring) word in volgorde van belangrikheid hieronder gelys:

10. Relevantheid van inligting tot bereiking van bedryfsdoelwitte

34. Mate waartoe die BIS voldoen aan gebruikersverwagtinge

21. Opleiding wat verskaf is vir die gebruik van die BIS

22. Algehele koste-effektiwiteit van die BIS

13. Doeltreffende gebruikersdokumentasie

20. Bevredigende regstelling van foute

17. Vinnige omkeertyd vir die veranderings aan die bestaande stelsel

3. Kennis van ontwikkeliings- en bedryfskostes van die BIS

24. Voorsiening van 'n ouditspoor

Totaal - al die gebruikers

Laastens word die 12 faktore gelys (verklaring van $70.0 \%$ )

soos verkry uit die totale populasie:

13. Doeltreffende gebruikersdokumentasie

10. Relevantheid van inligting tot bereiking van bedryfsdoelwitte

36. Geoutomatiseerde gebruikersmanipulasie van die BIS

20. Bevredigende regstelling van foute

34. Mate waartoe die BIS voldoen aan gebruikersverwagtinge

7. Suksesvolle stelseltoetsing

26. Gebruikersvertroue in die BIS

32. Algehele koste-effektiwiteit van die BIS

22. Volume (toepaslike hoeveelheid) van uitvoerinligting uit die BIS

24. Voorsiening van 'n ouditspoor

\section{Algemene opmerkings}

Uit die vier statistiese evalueringslopies wat voltooi is, is daar slegs twee attribute wat in al vier se kritiese suksesfaktore gelys is. Dié attribute is:

10. Relevantheid van inligting tot bereiking van bedryfsdoelwitte

34. Mate waartoe die BIS voldoen aan die gebruikersverwagtinge

'n Verdere vier attribute kom elk in drie van die evalue-

ringslopies te voorskyn, naamlik:

3. Kennis van ontwikkelings- en bedryfskostes van die BIS

7. Suksesvolle stelseltoetsing

22. Volume (toepaslike hoeveelheid) van uitvoerinligting uit die BIS

26. Gebruikersvertroue in die BIS

Dit is merkwaardig dat elke groep waarop 'n aparte ontleding gedoen is, sy eie groep kritiese sukses faktore het ter bereiking van 'n suksesvolle bestuursinligtingstelsel. Gevolglik sal dit nie wenslik wees om die verskillende groepe in totaliteit te probeer aanspreek om hul behoeftes te probeer bevredig nie. Elke groep sal op sy eie aangespreek moet word om so maksimum bevrediging te bewerkstellig.

\section{Bespreking en aanbevelings}

'n Baie moeilike situasie waarin die bestuursinligtingsafdeling homself nou bevind, is die keuse oor watter een van die genoemde groepe se behoeftes eerste aangespreek moet word. Die wenslikste situasie sal wees om elk van die cerste drie groepe gebruikers se behoeftes ter verbetering van die diens gelyktydig aan te spreek. Dit is natuurlik baie moeilik.

Om hierdie rede is ook 'n statistiese evaluering van die totale bestuursinligting gebruikerskorps gedoen. Indien daar aan die volgende gelyste faktore aandag geskenk word, kan daar 'n merkwaardige verbetering in die totale dienslewering van die stelselontwikkelingsdepartement aan die gebruikers wees. Hierdie lys van faktore kan beskou word as die 'goue middeweg' om te volg om soveel gebruikers in so 'n spoedig moontlike tyd tevrede te probeer stel. Uit die totale evaluering word die volgende voorstelle gemaak:

- Aandag moet geskenk word aan gebruikersdokumentasie en die korrekte gebruik daarvan. Gebruikers moet opgelei word om hierdie dokumentasie effektief te kan gebruik ter ondersteuning van bestuursinligtingverslae wat hulle ontvang.

- Om die probleem van toepaslikheid van inligting te oorkom, word voorgestel dat gebruikers toegang moet verkry tot die bestuursinligtingdatabasis, sodat hulle hul eie onttrekkings kan doen soos dit benodig word. Hier moct gekyk word na die moontlikheid om die pakket Ergo, of dalk Mapper, te gebruik om die inligting meer geredelik beskikbaar te stel aan die gebruikers.

- Datamanipulasie en die sogenaamde 'wat as' ('what if') verwerking word hoofsaaklik verlang deur die top-en middelbestuursgroep. Om hierdie probleem uit die weg te ruim, sal die rekenaar wat tans in oorweging geneem word, aangekoop moet word. Die nodige ontwikkeling sal dan op die rekenaar gedoen moet word om dit ten volle in bedryf te kan stel. Hierdie rekenaar sal ook 'n bydra kan lewer tot sy gebruikers rondom die toepaslikheid van inligting en hoeveelheid detail benodig.

- By foutregstelling moet daar krities gekyk word na die diens wat stelselontwikkeling lewer. Hier moet 'n persoon of persone met die nodige kennis, agtergrond en vaardighede die taak opgelê word om toe te sien dat enige foute wat herstel is nie dalk tot gevolg het dat ' $n$ volgende fout sy opwagting maak nie. Die sterkste moontlike klem moet op kwaliteit werk gelê word.

- Die mate waarin die bestuursinligtingstelsel aan die gebruiker se verwagtinge voldoen, kan moontlik verbeter word indien streekskoördineerders aangestel word wat aandag sal skenk aan doeltreffende kommunikasie tussen gebruikers in die streke en die personeel van stelselontwikkeling. Voorstelle ter verbetering van die diens kan sodoende versamel word en moontlik geïmplementeer word na gelang van omstandighede. Kommunikasie sal hier die klem moet dra sodat al die betrokke partye te alle tye op die hoogte van sake gehou word.

- Stelselontwikkeling sal indringede aandag moet skenk an die kwaliteit van die finale produk wat an die gebruiker beskikbaar gestel word. Hier word verwys na 'n baie deeglike stelseltoetsing wat gedoen moet word by 
die implementering van nuwe modules. Die produk wat die gebruiker ontvang, moet te alle tye korrek wees. Een enkele fout kan lei tot onskatbare skade ten opsigte van verkeerde besluitneming en die beeld van die bank.

- Vertroue moet opgebou word onder die gebruikers van bestuursinligting. Stelselontwikkeling moet aan die gebruikers genoegsame bewys kan lewer dat inligting wat verskaf word, akkuraat en korrek is. Dit sal slegs suksesvol gedoen kan word indien die stelselontwikkelingsdepartement met $100 \%$ sekerheid self kan sê dat hul produkte van die heel beste gehalte is.

-Opleiding moet aan die gebruikers verskaf word wat vir hulle meer inligting sal deurvoer oor die kostes rakende die bedryf en ontwikkeling van 'n bestuursinligtingstelsel binne die bank.

-Die volume uitvoerinligting is ook 'n faktor wat gelys word uit die evaluerings. Hierdie aspek kan ook aangespreek word deur die daarstelling van die Ergo/Mappertoegang na die bestuursinligting databasis. Dit behoort die gebruikers die geleentheid te gee om self meer sê te kan hê oor die volume en die formaat van hul uitvoerinligting.

- 'n Laaste punt wat aandag behoort te geniet in die eerste fase van diensverbetering aan die gebruikers, is die daarstelling van 'n doeltreffende ouditspoor. Soos reeds vroeër genoem, sal daar deeglike ondersoek ingestel moet word na wat presies so 'n ouditspoor behels.

Indien die bogenoemde tien voorstelle suksesvol geïmplementeer is, sal daar reeds baie ver gevorder wees in die rigting van diensverbetering aan die bestuursinligtinggebruikers.

\section{Opsomming}

Dit sal wel nodig wees om elke individuele groep gebruikers aan te spreek aangesien hul behoeftes so uiteenlopend is. Hierdie aanspreking kan volg op die suksesvolle implementering van die aanvanklike aanbevelings. Daar sal egter krities geëvalueer moet word oor watter groep gebruikers se behoeftes volgende aandag moet geniet.

Uit die bogenoemde besprekings is dit baie duidelik dat daar ' $n$ besliste behoefte bestaan vir 'n tegniese analis binne die bestuursinligtingafdeling. Die taak van hierdie persoon sal wees om 'n doeltreffende kommunikasiekanaal tussen die gebruikers en die stelselontwikkelingsdepartement daar te stel. Verder sal dit wenslik wees dat alle navrae rakende die bestuursinligting aan die persoon gerig word, aangesien dit 'n aansienlike tydsbesparing te weeg sal bring vir die ontwikkelingspersoneel. Hierdie persoon sal moet omsien na die 'bemarking' van die bestuursinligting, asook enige dokumentasie en opleiding wat benodig word deur die gebruikers van bestuursinligting.

Voordat daar werklik voortgegaan kan word met die bemarking van die bestuursinligtingdepartement binne hierdie bank sal ' $n$ baie duidelike definisie op skrif gestel moet word oor wat as bestuursinligting gesien word. Daar sal 'n duidelike onderskeid getref moet word tussen bestuursinlig ting en transaksieverwerkingsinligting. Hierdie verskil en definisie sal dan vervolgens aan die personeel binne die bank deurgegee moet word.

Daar moet deeglik besef word dat hierdie probleme nie oornag opgelos kan word nie maar, dat dit 'n lang proses is wat stap-vir-stap aangepak sal moet word. Solank die gebruiker ' $n$ volgehoue beweging in die regte rigting sien, sal hulle meer positief oor die totale aangeleentheid wees.

\section{Verwysings}

Bailey, J.E \& Pearson, S.W. 1983. 'Development of a tool for measuring and analysing user satisfaction'. Management Science, Vol. 29, No. 5: 530-545.

Bruwer, P.J.S. 1987. 'Strategic planning models for information systems'. Quaestiones Informaticae. Vol. 5, No. 3: 45-49.

Dixon, W.J. (ed.) 1983. BMDP statistical sofiware. Berkeley University of California Press.

Van der Wath, D. 1990. 'n Bestuursinligtingstelsel vir ' $n$ spesifieke bankinstelling. Ongepubliseerde skripsie, $\mathrm{PU}$ vir $\mathrm{CHO}$, Potchefstroom. 